\title{
REFERENCES TO HUMAN RIGHTS IN CODES OF ETHICS FOR PSYCHOLOGISTS: CRITICAL ISSUES AND RECOMMENDATIONS. PART $1^{1}$
}

\author{
Janel Gauthier \\ School of Psychology \\ Laval University \\ 2325, rue des Bibliothèques, Quebec City, Quebec, G1V 0A6, Canada
}

\begin{abstract}
There are codes of ethics in psychology that explicitly refer to human rights. There are also psychologists interested in the protection and promotion of human rights who are calling for the explicit inclusion of references to human rights in all psychology ethics codes. Yet, references to human rights in ethics documents have rarely been the focus of attention in psychological ethics. This article represents the first part of a two-part article series focusing on critical issues associated with the inclusion of references to human rights in the ethical codes of psychologists, and recommendations about how psychological ethics and the human rights movement can work together in serving humanity. The first part of the article series examines issues pertaining to the interpretation of references to human rights in codes of ethics for psychologists, and the justifications for including these references in psychological ethics codes. The second part of the article series examines how the Universal Declaration of Ethical Principles for Psychologists can be used to extend or supplement codes of ethics in psychology, how ethical principles and human rights differ and complement each other, and how psychological ethics and the human rights movement can work together in serving humanity and improving the welfare of both persons and peoples.
\end{abstract}

Key words: codes, ethics, human rights, ethical principle, universal declarations, psychological ethics

\section{Introduction}

References to human rights in ethics documents have rarely been the focus of discussion or critique in psychological ethics. Still, some codes of ethics in psychology explicitly refer to human rights (e.g., American Psychological Association, 2017; Australian Psychological Society, 2007; Canadian Psychological Association, 2017). Furthermore, some psychologists wishing psychology to play a more active role in the protection and promotion of human rights are calling for the explicit inclusion of references to human rights into all psychology codes of ethics (e.g., Hagenaars, 2016).

${ }^{1}$ This article is based on an award address presented at the $75^{\text {th }}$ Conference of the International Council of Psychologists in New York City, NY, 28-30 July 2017 and an invited keynote address presented at the First Pan-African Congress of Psychology in Durban, South Africa, 18-21 September 2017. 
The present article represents the first part of a two-part article series focusing on critical issues associated with the inclusion of references to human rights in the ethical codes of psychologists, and recommendations about how psychological ethics and the human rights movement can work together in serving humanity. The purpose of the present article is to identify and examine the difficulties in integrating references to human rights in codes of ethics. The recommendations about how to address those issues and how psychological ethics and the human rights movement can work together in serving humanity will be made in a subsequent that will represent the second part of the two-part article series.

The first part of the article series opens with a look at facts concerning references to human rights in codes of ethics in psychology (prevalence, terms used, etc.). This is followed by an examination of the origin, historical development and contemporary meaning of human rights. Then, the different approaches to the interpretation of human rights in ethics codes and the justifications for referring to human rights in codes are analyzed. The second part of the two-part article series will open with an introduction to the Universal Declaration of Ethical Principles for Psychologists (2008) and a consideration of how it can be used to extend or supplement codes of ethics in psychology. Afterwards, the ways ethics and human rights differ and complement each other will be discussed. Then, the importance and the role of human rights education in psychology will be highlighted and specific recommendations will be made. The second part of the two-part article will close with further recommendations about the promotion of ethics and human rights in a globalizing world.

\section{References to Human Rights in Codes of Ethics: Some Facts}

Psychology's codes of ethics articulate and promote ethical principles, and sets of specific ethical standards for the professional conduct of psychologists. They serve both to guide and to educate psychologists. Some of these codes incorporate references to human rights. The prevalence of these references and the way codes refer to human rights are relatively unknown.

Recently, Sinclair (2017) reviewed the national psychology ethics codes available online in English on the website of the International Union of Psychological Science (http:// psychology-resources.org/explore-psychology/standards/ethics/codes-of-ethics-ofnational-psychology-organisations/) to identify the extent to which codes of ethics in psychology refer to human rights and how they incorporate or support the concept of human rights. Her sample included codes of ethics of 27 countries. A list of those countries, including the date the code was published or last revised, is presented in Table 1. Her analysis of the codes revealed that: 13 (48\%) of the countries mention the words "human rights"; 6 (22\%) mention the words "moral rights"; 24 (89\%) mentioned the words "rights", "basic rights", "legal rights", "civil rights", or "constitutional rights"; 4 (15\%) mention both "moral rights" and "human rights"; and 4 (15\%) mention "international law" or "international declarations". As these results demonstrate, there is a fair amount of inconsistency in codes' use of these various terms, which sometimes are also used interchangeably within a code as if they had the same meaning. As to the term "human rights" itself, it is sometimes used in a generic way, not referring necessarily to human 
rights as set out in the Universal Declaration of Human Rights (UDHR) (United Nations, 1948).

National codes of ethics reviewed by Sinclair (2017): List of countries and date the code was published or last revised

\begin{tabular}{|l|l|l|}
\hline Australia (2007) & Iran (n.d.) & Romania (n.d.) \\
Britain (2009) & Ireland (2010) & Russia (2012) \\
Bulgaria (2007) & Israel (n.d.) & Serbia (2000) \\
Canada (2017) & Japan (n.d.) & Singapore (n.d.) \\
China (2007) & Latvia (n.d.) & Slovenia (n.d.) \\
Colombia (2000) & Malta (n.d.) & South Africa (2004) \\
Croatia (n.d.) & Netherlands (2007) & Trinidad/Tobago (n.d.) \\
Estonia (n.d.) & New Zealand (2002) & Turkey (2004) \\
Hong Kong (2012) & Philippines (2008) & United States (2002/2017) \\
\hline
\end{tabular}

The inconsistency observed in references to "human rights" in codes of ethics is understandable. The concept of "rights" is relatively complex. There is considerable literature regarding its history, underlying philosophy, and the many different types of rights. Very few countries provide a definition of any of the type of rights mentioned in their code. The definitions provided for the same type of rights vary across codes of ethics. In the Canadian code of ethics [7], for example, the term "moral rights" is defined as follows:

"'Moral rights' means the fundamental and inalienable rights of persons and peoples. They apply to all human beings and are grounded in moral reasoning (e.g., reasoning that helps to identify and justify them). Some aspects of moral rights may be contained within and protected by international, regional, and national declarations, constitutions, laws, and statutes (e.g., human rights declarations; just laws defining the legal and civil rights of persons or peoples living in a country or region). However, other aspects may not be so contained or protected". (Definition of moral rights: Canadian Psychological Association, 2017).

In the Australian code of ethics (Australian Psychological Society, 2007), the term "moral rights" is defined only by stating the following: "Moral rights incorporate universal human rights as defined by the United Nations Universal Declaration of Human Rights that might or might not be fully protected by existing laws" (Definition of moral rights: Australian Psychological Society, 2007).

For the purpose of the present article, however, it is important to point out that the term "moral rights", as defined in the Australian and the Canadian codes of ethics (Australian Psychological Society, 2007; Canadian Psychological Association, 2017), refers to human rights that may or may not be fully protected by existing laws and statutes. Of particular significance to psychologists, for example, are rights to equal justice, fairness and due process; and to developmentally appropriate privacy, self-determination, and autonomy. Protection of some aspects of these rights may involve encouraging practices which may not be contained within or controlled by current laws and statutes.

Scientific and professional organizations of psychology rarely justify why they incorporate human rights in their codes of ethics. They simply do it. However, it is quite reasonable to suggest that they do it for one or several of the following reasons: to raise 
awareness, sensitivity, and knowledge about human rights; to complement and strengthen ethical standards of conduct; to give increased legal validity to the standards set out in their ethics code; to demonstrate the close relationship between ethics and human rights; to demonstrate commitment to promotion and protection of human rights. Such justifications for the integration of human rights in codes of ethics are admirable and laudable. However, how references to human rights in codes of ethics should be interpreted is unclear. As shown in the next section, the concept of human rights has evolved over time and different groups and cultures have developed different definitions and interpretations of human rights. Furthermore, in addition to the interpretation problems, one has also to wonder whether references to human rights add something to ethics codes that cannot be remedied or supplemented in another and a more effective way?

\section{The Concept of Human Rights}

Let us now examine how documents asserting human rights have evolved over the centuries and how politics have shaped their development and interpretation.

The ideas of human dignity and a superior supernatural norm system have their roots in antiquity. However, the belief that everyone, by virtue of being human, is entitled to certain human rights is relatively new. Unlike the ethical principles found in modern codes of ethics (Sinclair, 2012), the concept of human rights is primarily the product of 17th- and 18th-century European thought, which has come into common currency only in the 20th century after the Nuremberg trials disclosed to the world the atrocities perpetrated by the Nazis before and during World War II (WWII) (Ishay, 2008). Human rights became a core objective of the United Nations (UN) when it was founded in 1945 (Mann, Gruskin, \& Grodin, 1999; Power, 2002). Today, human rights are almost always assumed to refer the documents associated with the UDHR (UN, 1948). These rights are based on theories of natural law and, therefore, are considered to be inherent in the nature of being human (Gauthier \& Pettifor, 2012). That is to say that individuals hold "human rights" simply because they are members of the human race. Because they are "natural", these rights are considered to be inalienable, inviolable, indivisible, undeniable and unchangeable. As such, they take priority over all other issues. By their nature, these rights are necessarily universal, and apply to everyone across all nations over all time with no exception for religion, language, culture, race, gender, ethnic origin, or any other status. This is true in discourse. But how true is this in practice? To shed some light on this highly important question, let us consider the origin, historical development and contemporary meaning of human rights.

\section{The Forerunners of the Universal Declaration of Human Rights}

The UDHR had forerunners. It did not represent the first attempt to identify and define moral imperatives for humans. The Ten Commandments (about 1,200 BCE) are perhaps one of the oldest examples of a list of religious and moral imperatives that are recognized (with minor differences in wording) as a moral foundation in Judaism, Christianity, and Islam. Over 1,200 years before the birth of Christ, these commandments were delivered from God to guide the behavior of humans. The Ten Commandments, although not using the language of human rights, are still honored today as a basic foundation for ethical human behavior. In addition to the moral conduct issues, the early 
prophets of all the world's great religions were deeply concerned about the oppression and abuse suffered by the common people at the hands of the ruling classes. Within the context of their time and place in history, they preached love and compassion and they demanded justice from ruling powers (Pettifor, 1996; Smith, 1991).

The Edict of Milan (313), a proclamation that permanently established religious toleration for Christianity within the Roman Empire, was the outcome of a political agreement concluded in Milan between the Roman emperors Constantine I ruling the West and Licinius the East.

The Magna Carta (1215), also called the "Great Charter of Freedoms", was the first document forced on an English King to limit the power of the king by law. Perhaps the most important legacy of the Magna Carta was establishing the foundation for the principle of "habeas corpus" protecting the individual against illegal imprisonment.

The English Bill of Rights (1689), which grew out of years of political unrest and civil war, was passed by the English Parliament to set strict limits on the royal family's legal prerogatives. It made the monarchy subject to the laws of parliament, thus ending the divine right of kings (we might add queens), a significant move from the rule of man to the rule of law.

The United States (U.S.) Declaration of Independence (1776) states "We hold these truths to be self-evident, that all men (sic) are created equal, that they are endowed by their Creator with certain unalienable Rights, that among these are Life, Liberty and the Pursuit of Happiness”. The U.S. Declaration provided a moral justification for an otherwise illegal war of independence from British colonization. It should be noted that the authority for these rights was attributed to the Creator.

From the French Revolution came the Declaration of Rights of Man and Citizen [In French: Déclaration des droits de l'homme et du citoyen] (1789) and the slogan "Liberty, Equality and Fraternity". The strongest emphasis was on equality and the Declaration called for the destruction of aristocratic privileges since all men were created equal before the law. Interestingly, the document did not make any statement about the status of women or slaves.

\section{The Universal Declaration of Human Rights}

The UDHR (UN, 1948) was a direct response to the exposure of the atrocities committed by the Nazis before and during WWII, and its message was that all nations must commit to protecting human rights of its citizens. The process of developing the UDHR was long and sometimes difficult. A great many people contributed their ideas on the content. Western countries addressed individual rights while non-western societies emphasized duties, responsibilities, and the collective good. Some countries placed more importance on economic, social and cultural rights. To complicate matters, the two superpowers of the time (the Union of the Soviet Socialist Republics and the United States of America) were in the early stages of the Cold War, an ideological battle with serious implications for human rights around the world. Moreover, the process of creating a universal declaration of human rights was seen by some member states as dominated by the victors in WWII to the neglect of non-western cultures. Certainly, the development of the UDHR was a political process in attempting to connect virtue with mechanisms 
for legal enforcement. In the end, the text was a compromise; many controversial issues were excluded and broad language was used (Glendon, 2001).

The UDHR was finally adopted by the UN General Assembly in December 1948. None of the 58 member states of the United Nations voted against the Declaration. However, eight nations chose to abstain (Belorussian Soviet Socialist Republic, Czechoslovakia, Poland, Saudi Arabia, South Africa, the Soviet Union, the Ukrainian Soviet Socialist Republic, and Yugoslavia) and two were absent (Honduras and Yemen). The countries that decided to abstain from voting did so for various reasons. The six communist countries objected to the strong wording of several provisions guaranteeing individual rights (e.g, freedom of speech, freedom of the press, freedom of religion, freedom to leave one's country) and claimed that the Declaration did not emphasize economic rights sufficiently; Saudi Arabia cited conflict with Islamic law that required religious devotion and patriarchal authority; apartheid South Africa could not agree to guarantees of racial equality and claimed that the Declaration was going too far (Morsink, 1999). As the voting reveals, the human rights, as set out in the UDHR, were not unanimously accepted.

As mentioned above, there were $58 \mathrm{UN}$ member states at the time the drafting of the Declaration. This membership was composed as follows: North and South America: 21 countries; Europe: 16 countries; Asia: 14 countries; Africa: 4 countries; and South Sea Islands: 3 countries (Morsink, 1999). As the composition of the UN membership at drafting reveals, Africa and Asia were vastly under represented, illustrated by the fact that Africa gave rise to over 30 independent states in the decade 1958 to 1968 (Harry Magdoff quoted in Morsink, 1999). This under-representation was compounded by and resulted from the fact that, at the time of drafting, many Asian and African countries were colonized by nations such as France and Britain who were involved in the drafting process. It is therefore the views of the colonizing, and not the colonized, which were represented.

The Drafting Committee included Eleanor Roosevelt (USA), Peng Chun Chang (Republic of China), Charles Habib Malik (Lebanon), William Roy Hodgson (Australia), Hernán Santa Cruz (Chile), René Cassin (France), Alexander E. Bogomolov (USSR), Charles Dukes/Lord Dukeston (United Kingdom) and John Peters Humphrey (Canada). Clearly, the Western domination of the drafting process is another issue.

The UN now has 193 member states, over three times the number at drafting. All of them have signed on in agreement with the UDHR. But what does it mean if the agreement is non-binding? The fact of the matter is that, today, the UDHR continues to be the focus of various criticisms (not only from outside the Western world, but also from within) (e.g., Freeman, 2008; Langlois, 2013; Rengger, 2011). A review of these criticisms is beyond the scope of this article. However, for the purpose of the present article, the key ones can be summarized as follows:

- Espouses primarily Western values and defines human rights in the Judeo-Christian tradition that fails to take into account the cultural and religious context of all nations, particularly non-western ones - Western imperialism (lack of universality).

- Content promotes virtue while enforcement and monitoring reflect political agendas.

- Human rights are often used to justify violence against those who are seen as oppressors, that is, those who deny freedom and dignity for others. Thus, if peaceful means to eliminate serious violations of human rights are impossible, then violent means 
become necessary. How ethical is such behavior? How can one justify such behavior? This too is a dilemma.

\section{The Emergence of Regional Human Rights Documents}

As the history of human rights documents reveal, documents asserting human rights have evolved over the centuries in how they articulate the virtues of freedom and equality for all human beings. Within seven decades, the UDHR has become the most important document in the world to define a standard for human rights, but not one that is universally accepted. There are states in different regions of the world that do not endorse human rights as set out by the UN, and that have developed their own specific cultural-political versions of human rights.

For example, the member states of the Organisation of the Islamic Conference (OIC) have created their own declaration of human rights. Adopted in 1990 by 45 member states of the OIC, it is called the Cairo Declaration on Human Rights in Islam (OIC, 1990). Proponents of the Cairo Declaration claim that it is not an alternative to the UDHR (UN, 1948), but rather complementary to it. As shown in the excerpts presented in Table 2, the Cairo Declaration reaffirms many of the individual human rights recognized in the UDHR.

Table 2

Excerpts from the Cairo Declaration on Human Rights in Islam (OIC, 1990)

\section{ARTICLE 1}

(a) [...]. All men are equal in terms of basic human dignity and basic obligations and responsibilities, without any discrimination on the grounds of race, color, language, sex, religious belief, political affiliation, social status or other considerations. [...].

ARTICLE 5

(a) The family is the foundation of society, and marriage is the basis of its formation. Men and women have the right to marriage, and no restrictions stemming from race, color or nationality shall prevent them from enjoying this right.

(b) Society and the State shall remove all obstacles to marriage and shall facilitate marital procedure.

They shall ensure family protection and welfare.

ARTICLE 6

(a) Woman is equal to man in human dignity, and has rights to enjoy as well as duties to perform; she has her own civil entity and financial independence, and the right to retain her name and lineage.

(b) The husband is responsible for the support and welfare of the family.

ARTICLE 11

(b) [...]. Colonialism of all types being one of the most evil forms of enslavement is totally prohibited. Peoples suffering from colonialism have the full right to freedom and self-determination. It is the duty of all States and peoples to support the struggle of colonized peoples for the liquidation of all forms of colonialism and occupation, and all States and peoples have the right to preserve their independent identity and exercise control over their wealth and natural resources.

ARTICLE 12

Every man shall have the right, within the framework of Shari'ah, to free movement [...] ARTICLE 17

(a) Everyone shall have the right to live in a clean environment [...].

(b) Everyone shall have the right to medical and social care [...]. ARTICLE 18

(a) Everyone shall have the right to live in security for himself, his religion, his dependents, his honor and his property. 
Unlike the UDHR, however, it also recognizes that peoples have the full right to freedom and self-determination and the right to preserve their independent identity and exercise control over their wealth and natural resources. Self-determination is mentioned in Articles 1 and 55 of the Charter of the United Nations (UN, 1945); however, there is no reference to the rights of peoples or of self-determination in the UDHR. That said, Article 24 states that "[a]1l the rights and freedoms stipulated in this Declaration are subject to the Islamic Shari'ah" and Article 25 follows with "[t]he Islamic Shari'ah is the only source of reference for the explanation or clarification of any of the articles of this Declaration". The reason for these statements is that, in the Islamic world, states recognize no authority or power but that of God, and no legal tradition apart from the sacred Islamic law. Because the Cairo Declaration limits almost all rights and freedoms protected by the UDHR, attempts to have it endorsed by the UN Commission on Human Rights (now the Human Rights Council) have met strong criticisms, including from liberal Muslim groups (Mayer, 1999; Mernissi, 2002; Carle, 2005). When it was submitted to the UN Human Rights Commission in 1992, the International Commission of Jurists strongly denounced it (UN Commission on Human Rights, 2003).

Another example of a regional initiative for the promotion and protection of human rights is the development of the Arab Charter on Human Rights by the League of Arab States (LAS, 2004). The Arab League has 22 members (including the suspended Syria). The Charter has been ratified by a total of 17 states. The LAS began work on the Charter in 1960, 12 years after the adoption of the UDHR. After several revisions, the document was adopted in 2004, and entered into force in 2008 (Rishmawi, 2010). In its preamble, the Arab Charter on Human Rights reaffirms the principles of the UDHR (UN, 1948). As shown in the excerpts presented in Table 3, the Arab Charter reaffirms many of the individual human rights described in the UDHR (e.g., the right not to be tortured, the right to free and informed consent, the right to justice).

Unlike the UDHR, however, it celebrates human rights as a gift of God to the Arab homeland. As it also reaffirms the provisions of the Cairo Declaration, the rights and freedoms in the Arab Charter are subject to the Islamic Shari'ah like those in the Cairo Declaration. On 24 January 2008, the UN High Commissioner for Human Rights, Louise Arbour, issued a statement in which she welcomed the entry into force of the Arab Charter on Human Rights by the League of Arab States as "an important step forward" to help "strengthen the enjoyment of human rights" (Arbour, 2008a; Schaefer \& Groves, 2009). Interestingly, in an unprecedented move aiming to respond to a UN Watch protest around the world urging immediate action (https://www.unwatch.org/issue-173-un-rights-chiefclarifies-stance-arab-charter/), she backed off six days later from her earlier endorsement of the Arab Charter. On 30 January 2008, she issued another statement saying that the "Arab Charter on Human Rights contains provisions that do not meet international norms and standards" and that her office "does not endorse these inconsistencies" (Arbour, 2008b). Concerns included the application of the death penalty for children, the rights of women and non-citizens, and the equating of Zionism with racism.

On another continent, the African States members of the Organization of African Unity (OAU) developed the African Charter on Human and Peoples' Rights (OAU, 1981). The OAU, now called the "African Union", has 55 sovereign states (52 republics and 3 monarchies). 
Excerpts from the Arab Charter on Human Rights (LAS, 2004)

\begin{abstract}
ARTICLE 5
1. Every human being has the inherent right to life.

ARTICLE 8

1. No one shall be subjected to physical or psychological torture or to cruel, degrading, humiliating or inhuman treatment.

2. Each State party shall protect every individual subject to its jurisdiction from such practices and shall take effective measures to prevent them. [...].
\end{abstract}

ARTICLE 9

No one shall be subjected to medical or scientific experimentation or to the use of his organs without his free consent and full awareness of the consequences [...].

ARTICLE 11

All persons are equal before the law and have the right to enjoy its protection without discrimination. ARTICLE 13

1. Everyone has the right to a fair trial that affords adequate guarantees before a competent, independent and impartial court [...].

ARTICLE 14

1. Everyone has the right to liberty and security of person.

ARTICLE 20

1. All persons deprived of their liberty shall be treated with humanity and with respect for the inherent dignity of the human person.

ARTICLE 33

1. The family is the natural and fundamental group unit of society; it is based on marriage between a man and a woman. [...]

2. The State and society shall ensure the protection of the family, the strengthening of family ties $[\ldots]$. They shall also ensure the necessary protection and care for mothers, children, older persons and persons with special needs [...].

ARTICLE 34

4. There shall be no discrimination between men and women in their enjoyment of the right to [...] employment and job protection and the right to receive equal remuneration for equal work. ARTICLE 39

1. The States parties recognize the right of every member of society to the enjoyment of the highest attainable standard of physical and mental health and the right of the citizen to free basis health-care services $[\ldots]$.

Adopted in 1981, the African Charter entered into force in 1986. It is a political document dedicated to eradicating all forms of colonialism from Africa, to coordinate and intensify their cooperation and efforts to achieve a better life for the peoples of Africa, and to promote international cooperation having due regard to the UN Charter (UN, 1945) and the UDHR (UN, 1948). Chapter 1 of the African Charter describes the rights, duties and freedoms of both individuals and peoples and the commitment to adopt legislative or other measures to give effect to them including the total liberation of Africa. The relationship of individuals and peoples is described as mutual. It is a duty of the state to protect the virtues of their historical traditions and to protect against loss of cultural identity in the face of global expectations. As with the rights documents of the U.S. and 
French revolutions, human rights are used to justify revolutions to obtain freedom, equality, justice and dignity. Article 20 of the African Charter speaks for itself:

1. All peoples shall have the right to existence. They shall have the unquestionable and inalienable right to self-determination. They shall freely determine their political status and shall pursue their economic and social development according to the policy they have freely chosen.

2. Colonized or oppressed peoples shall have the right to free themselves from the bonds of domination by resorting to any means recognized by the international community.

3. All peoples shall have the right to the assistance of the States parties to the present Charter in their liberation struggle against foreign domination, be it political, economic or cultural.

\section{Summary and Conclusions}

In summary, a review of the history of human rights demonstrates an evolution of discourse from the rights of small groups to global inclusiveness as well as a political response to issues of the day. Political agendas have both supported and undermined the promotion of human rights. The history of the UDHR and many of its forerunners reveals political disagreements and struggles for power that often led to violence, killing and civil war. Those who created rights and freedom documents did so in the context of freeing people from exploitation and oppression. History reveals a developmental process in which the concept of human rights becomes more inclusive of peoples and of a wider range of human needs. Yet, today, we still see barbaric struggles for power documented on daily newscasts. We recognize human rights achievements, we recognize the failure to achieve universality, and we recognize that strategies must be considered that match the social realities of the 21 st century.

The history of the UDHR does not support the belief that human rights as defined by the UDHR are truly unalienable, undeniable, immutable, unchangeable, inviolable, absolute. The concept of human rights is neither a unitary nor a universal construct. It has evolved and become more inclusive over time. However, it has not achieved "universality". Under the appearance of using a universal principle, the interpretation of human rights law reflects the social foundations of different countries and regions. Human rights are political in their creation and in their attempts at enforcement. Human rights documents are created by people and can be changed by people.

The UDHR is an example of a secular document; the Cairo Declaration on Human Rights in Islam (OIC, 1990) or the Arab Charter of Human Rights (LAS, 2004) are examples of documents based on religion. The theory of God-given or Natural Law gives both types of documents the appearance of superhuman authority, but does not allow for revisions to reflect the changing needs of society. The authority for human rights is neither divine, nor based on natural law, but rather created by those with the power and position to create, persuade and /or enforce. There are several declarations of human rights available today with both similarities in humanitarian values and differences in political agendas. History discloses the connection between "rights" and current issues and concerns of the day. We have given examples of these connections in Islamic, Arabic, African, North American

and European societies. The question has been raised, "Does the truth matter if the declaration works for the betterment of society and its members"? 


\section{The Interpretation of References to Human Rights in Codes of Ethics}

Sinclair's analysis of codes of ethics (Sinclair, 2017) has revealed that most references to human rights in codes of ethics are made without providing a definition of the term(s) used to refer to human rights in the document. How does a psychologist interpret a reference to human rights in a code of ethics if the construct is not defined in the code? Furthermore, an overview of the historical development and contemporary meaning of human rights show that the concept of human rights is neither a unitary nor a universal construct. It has evolved and become more inclusive over time, but it has not achieved "universality". How does a psychologist interpret a reference to human rights in a code of ethics in the absence of a universally acceptable definition of human rights?

Several approaches have been submitted to overcome the problem of interpretation. As Allan (2013) has shown in a critical analysis of the issues related to references to human rights in psychology's ethics codes, none of them are satisfactory. For example, it has been submitted that human rights are the rights set out in specific international law instruments, but it is not clear exactly what obligations this places on psychologists. To interpret a reference to human rights in a code of ethics as a reference to law makes little sense as the rule of law provides that no person, including a psychologist, is beyond the law. Even where there is no reference to human rights in their ethical codes, psychologists are bound by the human rights provisions in the constitutions and other domestic legislation of the jurisdiction where they reside or work - of course, while psychologists must be respectful of democratically established law, it is important to remember here that they are expected to prioritize ethics if there is conflict between ethics and the law. Psychologists are not automatically bound by the UN treaties as they are instruments of international law (as a general rule, those bind countries, not individuals). Psychologists are subject to only those aspects of the UN treaties which form part of the domestic law of the jurisdiction in which they reside or work. In practice, this means that there are many provisions of the UN instruments that psychologists are not legally bound to adhere to.

That said, as codes of ethics are aspirational documents, it is possible to require in them that psychologists respect the whole body of international human rights law, even where their governments have not ratified a treatment or incorporated it in domestic legislation. This is what the Australian Psychological Society does in its code of ethics which defines moral rights as "human rights that might or might not be fully protected by existing law" (Definition of moral rights; Australian Psychological Society, 2007). The problem with this approach is that it requires psychologists to adhere to all of the UN instruments, which makes little sense as these instruments are meant to bind states, not individuals. A further difficulty is that it is unclear is to whom psychologists, as psychologists, owe an obligation and what the nature of that obligation is. For example, one of the articles in the International Covenant on Economic, Social and Cultural Rights (UN, 1966) places an obligation on states to take steps to ensure that their citizens have an adequate standard of living, but it does not tell psychologists what exactly their obligations are and to whom they owe them.

Despite these difficulties, one could argue that references to human rights in codes of ethics are justified if they add something to codes that are lacking and cannot be 
remedied in another way. But do they add something to codes? The evidence indicates that they do not. First, they do not add to the theoretical basis of codes: Both human rights and ethics codes of Western psychologists are closely linked with Kant's moral philosophy which recognizes that humans have an intrinsic worth, that is, dignity. Second, they do not add to the guiding moral framework of codes: As previously demonstrated in the present article, human rights are neither a unitary nor a universal construct.

Where does that leave us? Is there another more practical way to extend and supplement limitations in codes? These questions, along with others, will be examined in the second part of this two-part article series.

\section{REFERENCES}

Allan, A. (2013). Are human rights redundant in the ethical codes of psychologists? Ethics \& Behavior, 23(4), 251-265.

American Psychological Association. (2017). Ethical principles of psychologists and code of conduct (as amended 2010, 2016). Washington, DC: Author.

Arbour, L. (2008a). Statement by UN High Commissioner for Human Rights on the Entry into Force of the Arab Charter on Human Rights. Retrieved from the United Nations High Commissioner for Human Rights website: http://www.unhchr.ch/huricane/huricane.nsf/view01/6C211162E43235FAC125 73E00056E19D?opendocument

Arbour, L. (2008b). Arab rights charter deviates from international standards, says UN official. UN News Centre. Retrieved from: http://www.un.org/apps/news/story.asp?NewsID=25447\#.WgJub3ZrzIU

Australian Psychological Society (2007). APS code of ethics. Melbourne, Australia: Author.

Bill of Rights (1689). In M.R. Ishay (2008). The history of human rights from ancient times to the globalization era (2nd ed., p. 86). Berkeley and Los Angeles, CA: University of California Press. Also retrieved from http://www.britannia.com/history/docs/rights.html

Canadian Psychological Association. (2017). Canadian code of ethics for psychologists (4th ed.). Ottawa: Author.

Carle, R. (April-June 2005). Revealing and Concealing: Islamist Discourse on Human Rights. Human Rights Review, 6(3). 122-137.

Declaration of Independence (1776). In M.R. Ishay (2008). The history of human rights from ancient times to the globalization era (2nd ed., p. 95). Berkeley and Los Angeles, CA: University of California Press. Also retrieved from http://www.ushistory.org/declaration/document/

Declaration of the Rights of the Man and the Citizen [Déclaration des droits de l'homme et du citoyen]. (1789). In M.R. Ishay (2008). The history of human rights from ancient times to the globalization era (2nd ed., pp. 82-83). Berkeley and Los Angeles, CA: University of California Press. Also retrieved in French from https://www.legifrance.gouv.fr/Droit-francais/Constitution/Declaration-desDroits-de-1-Homme-et-du-Citoyen-de-1789

Edict of Milan. (313). Retrieved from http://www.holyspirit-al.com/ourpages/auto/2011/7/28/60780317/ edict $\% 20$ of $\% 20$ milan.pdf

Freeman, M. (2008). Human Rights. In P. Burnell \& V. Randall (Eds.), Politics in the Developing World (pp. 353-372). Oxford: Oxford University Press.

Gauthier, J., \& Pettifor, J.L. (2012). The tale of two universal declarations: Ethics and human rights. In M.M. Leach, M.J. Stevens, G. Lindsay, A. Ferrero, \& Y. Korkut (Eds.). The Oxford Handbook of International Psychological Ethics (pp. 113-133). Oxford, England: Blackwell Publishing. 
Glendon, M.A. (2001). A world made new: Eleanor Roosevelt and the Universal Declaration of Human Rights. New York, NY: Random House.

Hagenaars, P. (2016). Towards a human rights based and oriented psychology. Psychology and Developing Societies, 28(2), 183-202.

Ishay, M.R. (2008). The history of human rights: From ancient times to the globalization era. Berkeley, CA: University of California Press.

Langlois, A.J. (2013). Normative and Theoretical Foundations of Human Rights. In M. Goodhart (Ed.). Human Rights: Politics and Practice (2nd ed., pp. 11-26). Oxford: Oxford University Press.

League of Arab States (2004). Arab Charter on Human Rights. Retrieved from http://www.jus.uio.no/ english/services/library/treaties/02/2-01/arab-human-rights-revised.xml

Magna Carta (1215). In D. Danziger, \& J. Gillingham (2003). 1215: The year of Magna Carta (p. 275). London: Hodder \& Stoughton. Retrieved from http://www.bl.uk/treasures/magnacarta/index. html

Mann, J.M., Gruskin, S., Grodin, M.A., \& Annas, G.J. (1999). Health and human rights: A reader. New York: Routledge.

Mayer, A. (1999). An assessment of human rights schemes. In Islam and Human Rights (p. 175). Westview: Westview Press.

Mernissi, F. (2002). Islam and Democracy (p. 67). Cambridge: Perseus Books.

Morsink, J. (1999). The Universal Declaration of Human Rights: Origins, drafting \& intent. Philadelphia: University of Pennsylvania Press.

Organization of African Unity. (1981). African Charter on Human and Peoples' Rights. Retrieved from African Commission on Human and Peoples' Rights website: http://www.achpr.org/instruments/ achpr/

Organization of the Islamic Conference. (1990). Cairo Declaration on Human Rights in Islam. Retrieved from http://www.fmreview.org/sites/fmr/files/FMRdownloads/en/FMRpdfs/Human-Rights/ cairo.pdf

Pettifor, J. (1996). Ethics: Virtue and politics in the science and practice of psychology. Canadian Psychology, 37, 1-12.

Power, S. (2002). A problem from hell: America and the age of genocide. New York: Harper Collins.

Rengger, N. (2011). "The World Turned Upside Down? Human Rights and International Relations after 25 Years”, International Affairs, 87(5), 1159-1178.

Rishmawi, M. (2010). The Arab Charter on Human Rights and the League of Arab States: An update. Human Rights and Law Review, 10(1), 169-178.

Schaefer, B.D., \& Grooves, S. (2009). Human wrongs: Why the United Nations is ill equipped to champion human rights. In B.D. Schaefer (Ed.). ConUNdrum: The limits of the United Nations and search for alternatives (pp. 131-169).

Sinclair, C. (2012). Ethical principles, values, and code of ethics for psychologists: An historical journey. In M.M. Leach, M.J. Stevens, G. Lindsay, A. Ferrero, \& Y. Korkut (Eds.). The Oxford Handbook of International Psychological Ethics (pp. 3-18). Oxford, England: Blackwell Publishing.

Sinclair, C. (2017). Reflections on the integration of human rights into codes of ethics. In P. Hagenaars (Chair). Psychology, Ethics and Human Rights: Uneasy bedfellows or good companions? Symposium conducted at the 15th European Congress of Psychology, Amsterdam, The Netherlands.

Smith, H. (1991). The world's great religions: Our great wisdom traditions. San Francisco: Harper.

United Nations. (1945). Charter of the United Nations. Retrieved from http://www.un.org/en/charterunited-nations/ 
United Nations. (1948). Universal declaration of human rights. Retrieved from http://www.un.org/en/ universal-declaration-human-rights/

United Nations. (1966). International Covenant on Economic, Social and Cultural Rights. Retrieved from http://www.ohchr.org/EN/ProfessionalInterest/Pages/CESCR.aspx

United Nations Commission on Human Rights (2003). Report of the United Nations High Commissioner for Human Rights and Follow-Up to the World Conference on Human Rights. Retrieved from https://reliefweb.int/sites/reliefweb.int/files/resources/8F242BA5A0D37AEFC1256CFD002F9 D3C-unhchr-feb03.pdf

Universal Declaration of Ethical Principles for Psychologists. (2008). Retrieved from http://www.iupsys. net/about/governance/universal-declaration-of-ethical-principles-for-psychologists.html

(C) Gauthier J., 2017

\title{
Article history:
}

Received: 30 December 2017

Revised: 8 February 2018

Accepted: 9 February 2018

\section{For citation:}

Gauthier, J. (2018). References to Human Rights in Codes of Ethics for Psychologists: Critical Issues and Recommendations. Part 1. RUDN Journal of Psychology and Pedagogics, 15(1), 7-21. doi: 10.22363/2313-1683-2018-15-1-7-21

\section{Bio Note:}

Janel Gauthier - PhD, Professor Emeritus at the School of Psychology of Laval University in Quebec City, Canada, and President of the International Association of Applied Psychology. Since 2002, ethics and human rights are the main focus of his research and publications. He has received numerous awards for his distinguished contributions to the international advancement of psychological ethics. He was the Chair of the international working group that developed the Universal Declaration of Ethical Principles for Psychologists. E-mail: janel.gauthier@psy.ulaval.

\section{ОТРАЖЕНИЕ ПРАВ ЧЕЛОВЕКА В ЭТИЧЕСКИХ КОДЕКСАХ ПСИХОЛОГОВ: КРИТИЧЕСКИЕ ЗАМЕЧАНИЯ И РЕКОМЕНДАЦИИ. ЧАСТЬ I}

\author{
Жанель Готье \\ Университет Лаваля \\ Рю де Библиотек, 2325, Квебек, Квебек G1V 0A6, Канада
}

\begin{abstract}
В психологии существуют этические кодексы, которые напрямую соотносятся с правами человека. В тоже время есть ряд психологов, заинтересованных в защите и поддержании прав человека, которые призывают к включению прямых ссылок на права человека во все психологические этические кодексы. Однако в психологической этике редко уделяется большое внимание вопросам ссылок на права человека в этических документах.
\end{abstract}


Данная статья представляет собой первую часть серии статей, посвященных полемическим вопросам, связанным с включением прямых ссылок на права человека в этические кодексы психологов, а также возможным рекомендациям о том, как психологическая этика и правозащитное движение могут работать вместе в служении человечеству. В данной статье рассматриваются вопросы относительно интерпретации отражения прав человека в этических кодексах психологов, а также обоснования включения непосредственных ссылок на права человека в эти кодексы.

Во второй части серии статей будет рассмотрено как «Универсальная декларация этических принципов для психологов» может быть использована для расширения или дополнения этических кодексов в психологии; каким образом отличаются этические принципы и права человека и как они дополняют друг друга; а также как совместное продвижение психологической этики и прав человека может способствовать улучшению благосостояния как отдельных людей, так и народов.

Ключевые слова: этика, права человека, этические принципы, этические кодексы психологов, психологическая этика, «Универсальная декларация этических принципов для психологов»

(C) Готье Ж., 2017

\section{История статьи:}

Поступила в редакцию: 30 декабря 2017

Принята к печати: 9 февраля 2018

\section{Для цитирования:}

Готье Ж. Отражение прав человека в этических кодексах психологов: критические замечания и рекомендации. Ч. I // Вестник Российского университета дружбы народов. Серия: Психология и педагогика. 2018. Т. 15. № 1. С. 7-21. doi: 10.22363/2313-1683-2018-15-1-7-21

\section{Сведения об авторе:}

Жанель Готье - PhD, почетный профессор Школы психологии Университета Лаваля (Квебек, Канада), президент Международной ассоциации прикладной психологии. С 2002 года этика и права человека являются основными направлениями его исследований и публикаций. Он получил многочисленные награды за выдающийся вклад в международное продвижение психологической этики. Он был председателем международной рабочей группы, которая разработала «Универсальную декларацию этических принципов для психологов». E-mail: janel.gauthier@psy.ulaval.ca 